\title{
Strategie di musealizzazione dinamica per nuovi ambiti di memoria: il progetto DHoMus
}

\author{
Alessandra Vezzi \\ Beatrice Stefanini
}

Abstract

La realtà museale, riflesso dei cambiamenti culturali che attraversano la storia di una società e del suo sviluppo, si struttura oggi in un'istituzione in costante divenire e nell'assidua riformulazione dei confini della sua identità. Essa si riconosce nella vocazione di 'luogo della memoria' in cui raccogliere e tramandare le testimonianze materiali e immateriali di un passato più o meno remoto che porta messaggi per uno che è ancora prossimo. Un compito questo che trova il suo compimento nella ricerca e nella costruzione di un dialogo vivo e attivo tra ciò che era, ciò che è e ciò che sarà. II museo contemporaneo si appresta oggi ad interrogarsi su quali siano le risposte tecnologiche che corrispondono, nel miglior modo, all'intento, di non facile soluzione, di coniugare la dimensione del bene esposto con quella del suo fruitore. II presente contributo illustra un progetto di musealizzazione, in corso di sviluppo, che vede coinvolti in una collaborazione strategica l'Università e le strutture museali di piccoli centri periferici della regione Toscana. II progetto denominato DHoMus si propone in tale contesto, attraverso la ricerca applicata, di impiegare le tecnologie più avanzate per le elaborazioni digitali, al fine di promuovere la valorizzazione delle strutture museali e la loro fruibilità da parte di un pubblico più ampio.

Parole chiave

museo diffuso, comunicazione museale, modellazione 3D, ologramma, fruizione multimediale.

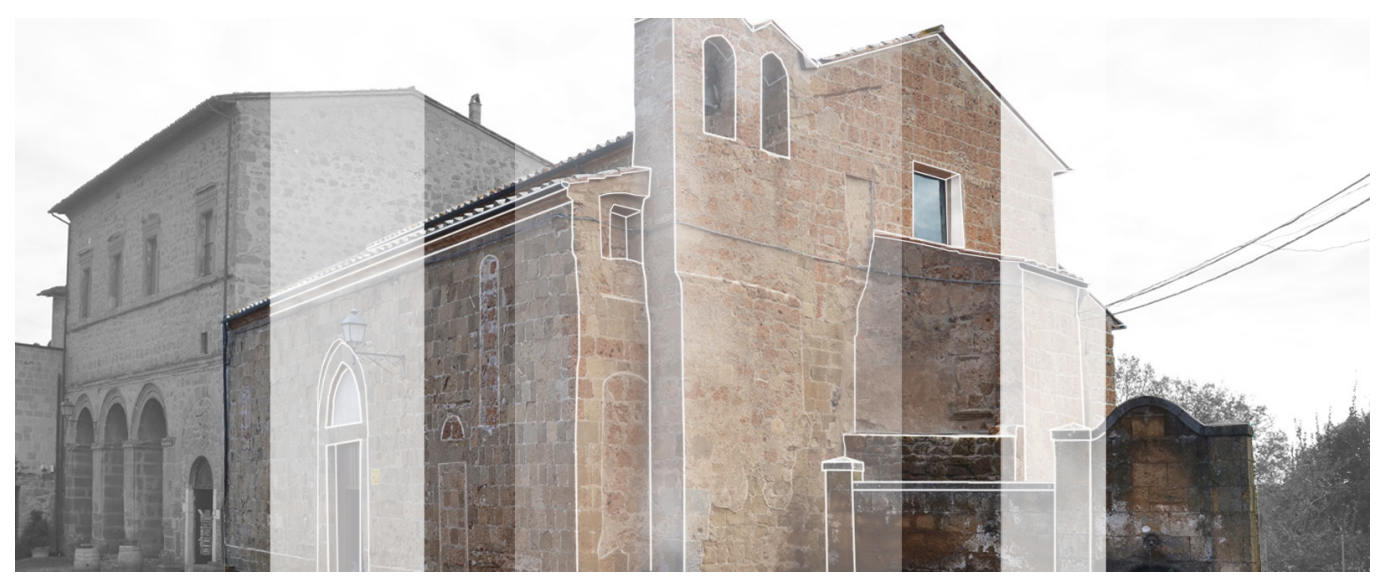




\section{La posizione della memoria}

La memoria storica, da quella individuale a quella collettiva, in qualunque campo culturale la si consideri, da sempre si presenta di fronte all'uomo, che vive nel proprio presente, come una realtà stante con cui il confronto diventa inevitabile. La storia ci racconta di una relazione che ha assunto varie inclinazioni a seconda dei diversi contesti, temporali, ma anche geografici in cui si è presentata. Seppur nelle loro differenze, tutte queste propensioni con cui l'uomo si è posto nei confronti della memoria hanno fatto emergere e chiarificare il peso di lei medesima, il suo valore in quanto parte essenziale alla definizione di una identità necessaria alla maturazione di un'autocoscienza, capace di proiettarsi attivamente nel futuro.

\section{Luogo di memoria: il museo}

Uno dei terreni in cui questo dialogo ha avuto luogo è indubbiamente quello del museo: ancor prima di impostarsi nell'istituzione che oggi ci è nota, esso ha portato all'incontro passato e presente e su questo ha posto le fondamenta della sua stessa configurazione. Se agli esordi, tra '400 e '500 questo incontro si risolveva in un'azione tutta tesa al collezionismo privato di opere d'arte o oggetti rari e mirabili; tra '700 e '800 si fa strada la consapevolezza dell'importanza culturale che il contatto con la storia riveste per tutti gli uomini, indistintamente dalla posizione di ciascuno all'interno di una società costituita: inizia così a figurarsi il museo moderno. A partire da qui la prospettiva della realtà museale si è andata sempre più ad ampliarsi sulla scorta di una riflessione che non ha mai smesso di interrogarsi sui termini del ruolo di questa istituzione, che, nel tentare di connettere passato e presente, si scopre anche tessitore del futuro. Arrivando all'oggi, in merito ai più recenti risultati del dibattito scientifico intorno a questo tema, eloquente è la definizione di 'museo', articolata nel 2007 dallo Statuto di ICOM, (International Council of Museums): "Il museo è un'istituzione permanente, senza scopo di lucro, al servizio della società, e del suo sviluppo, aperta al pubblico, che effettua ricerche sulle testimonianze materiali ed immateriali dell'uomo e del suo ambiente, le acquisisce, le conserva, e le comunica e specificatamente le espone per scopi di studio, educazione e diletto" [I]. La cultura contemporanea non pensa più al museo solo come un edificio preposto alla raccolta e alla custodia del patrimonio ma, piuttosto, come un'istituzione impegnata nella costante ricerca di uno scambio dialettico, critico e creativo con esso, tramite la strada della conservazione, mai abbandonata, della valorizzazione e della progettazione. La grande missione e sfida con la quale la musealizzazione, dall'epoca moderna ad oggi, si misura è quella di riuscire ad attualizzare la memoria, la sua eredità; di far sì che essa non finisca per essere solo un assioma lontano da assumere, ma una realtà da vivere come parte del tempo presente. L'ultima frontiera degli studi museologici, in particolar modo nel contesto italiano, hanno portato alla formulazione e all'affermazione dell'idea di 'museo diffuso', come modello di costruzione di una rete museale che estende la sua azione all'esterno, al territorio e alla popolazione, come è stato illustrato in occasione dell'Intermediate Conference, RIPAM 8.5 [Aiello 2020].

\section{La comunicazione del museo}

Considerato l'odierno contesto sociale e culturale, dove il continuo sviluppo tecnologico ha introdotto nei diversi ambiti della vita dell'uomo nuovi meccanismi di trasmissione, nella dimensione del museo contemporaneo, l'aspetto comunicativo è diventato un elemento determinante all'interno della strategia di fruizione adottata [Gabellone 20 I 4a, pp. 45-56]. La comunicazione museale, lontana dall'impostazione classica, si volge alla sperimentazione e all'approfondimento di nuovi sistemi che, basandosi su linguaggi di tipo visuale, uditivo e tattile, si rendono capaci di apportare un maggior coinvolgimento del pubblico [Di Pietro 2017, pp. 4-I I]. II progressivo interesse, che la realtà museale inter- 
nazionale mostra di avere nei confronti dell'impiego delle nuove tecnologie interattive, oltre ai motivi sopracitati, risponde indubbiamente anche ad altre criticità che questo particolare ambito della cultura ha individuato, e che si trova a dover affrontare. Note sono infatti tutte le questioni relative alla decontestualizzazione del patrimonio musealizzato, sia mobile che immobile; questioni particolarmente significative soprattutto quando si parla dei beni archeologici e monumenti di rilevanza storica e architettonica. II riferimento è diretto a quei "siti che, in condizioni limite, risultano completamente inaccessibili"; a quelle categorie monumentali, che "risultano scarsamente accessibili perché ubicati in posizioni sfavorevoli o perché la loro stessa conformazione ne rende difficile la fruizione", e per le quali "l'esigenza conservativa impone scelte drastiche che limitino o scongiurano i pericoli indotti da un numero elevato di visitatori" [Gabellone 20I4a, pp. 45-56]. Ai presenti casi inoltre vanno aggiunte le conseguenze di quella prassi, ormai consolidata, di 'spogliare' i siti archeologici degli elementi più preziosi, catalogare ed esporre i reperti in edifici museo, e raccontare il sito per mezzo di forme di rappresentazioni di difficile comprensione per i non specialisti. Azioni di questo tipo non possono che portare ad una frammentazione dei contenuti propri del bene e con ciò ad una trasmissione parziale e confusa delle conoscenze, impoverendo così l'efficacia dell'azione comunicativa museale. Di fronte a tali situazioni, la tecnologia proveniente dallo spazio virtuale - come la modellazione digitale 3D, l'animazione grafica interattiva e tridimensionale - si dimostra un valido strumento per la formulazione di protocolli metodologiche, che potenziando la capacità comunicativa della rappresentazione, favoriscono, e in taluni casi rendono possibile, la fruizione del bene culturale da parte del pubblico ampio e diversificato.

\section{Progetto DHoMus}

Nell'ambito delle tematiche finora descritte, ha preso avvio nel marzo 2020, il progetto DHoMus, condotto in collaborazione fra il Dipartimento di Architettura (settore scientifico disciplinare ICAR/17) dell'Università degli Studi di Firenze, e in qualità di Operatori della filiera culturale e creativa regionale, il Museo diocesano Palazzo Orsini di Pitigliano, e il Museo civico archeologico "Isidoro Falchi" di Vetulonia [2]. A fronte del ruolo cardine che la realtà museale gioca in campo alla salvaguardia del patrimonio culturale e in linea con l'emergente idea di 'museo diffuso', lo studio si propone di progettare percorsi conoscitivi tesi al superamento della mera contemplazione estetica dei beni culturali, ma capaci di portare in evidenza primaria i loro valori intrinseci. Il progetto intende avvalersi dell'utilizzo delle tecnologie più avanzate per la produzione di elaborazioni digitali (video, proiezioni olografiche, animazioni) e ausili tattili, a partire dai quali applicare protocolli d'intervento di musealizzazione dinamica.

Il formato digitale è un mezzo che ha sempre permesso di elaborare contenuti in grado di coinvolgere l'osservatore, consentendo una conoscenza dell'argomento con un approccio didattico informativo. La rappresentazione virtuale tridimensionale dell'ologramma, qui proposta, si pone in modo innovativo nei confronti delle nuove forme di comunicazione. L'utente, quindi, viene portato ad essere attratto da questo tipo di visualizzazione, che gli permette di muoversi attorno all'ologramma avendo l'illusione di poterlo guardare da più lati. Attualmente la ricerca sta sperimentando l'utilizzo di ologrammi a piccola scala da inserire in vetrine olografiche già presenti sul mercato e punta, per il futuro ad un loro sviluppo sempre più a grande scala e utilizzando tecnologie immersive sempre più coinvolgenti. Nel corso del progetto saranno sperimentate varie tecnologie per ottenere i diversi prototipi e modelli di fruizione adattati ai diversi target tecnologici. Infine, verranno organizzati eventi pilota presso i musei e aree archeologiche esterne per testare il funzionamento e le potenzialità divulgative e di valorizzazione.

La dinamicità di tale sistema vuole operare sul rapporto stesso tra visitatore, museo e sito archeologico o monumento: con ciò risulta fondamentale la possibilità di realizzare e rendere accessibili tramite l'esperienza sensoriale diretta, contenuti digitali di alcuni soggetti musealizzati opportunamente selezionati. L'obiettivo perseguito, dunque, guarda tanto alla 
documentazione e conservazione del patrimonio museale che alla valorizzazione, promuovendo la comunicazione e la divulgazione. È previsto, inoltre, il fine ultimo di elaborare metodologie d'impiego che possano rendere disponibili e sostenibili anche per musei periferici soluzioni altamente tecnologiche.

\section{In itinere}

Le attività del progetto DHoMus hanno svolto la sua prima annualità di lavoro secondo il seguente metodo di approccio:

Prima fase. Attraverso una serie di sopralluoghi preliminari, con i quali è stato accertato lo stato attuale dei due musei e dei siti afferenti. Questo momento ha compreso inizialmente lo studio storico del luogo, dei complessi museali, del contesto territoriale in cui questi si inseriscono e la raccolta del materiale già presente e disponibile per le prossime lavorazioni. Si è proceduto poi all'analisi delle sedi nel dettaglio, con particolare riguardo alle loro funzioni, ai percorsi e ai contenuti.

Seconda fase. Questo passaggio si è articolato nella ricerca dei soggetti di particolare rilevanza (dall'architettura all'oggettistica) che potessero essere mostrati in formato digitale ed entrare a far parte del racconto che si articola nel percorso museale. Contemporaneamente, sono stati valutati quali potessero essere i supporti tecnologici più adeguati per avere una migliore rappresentazione dei diversi temi scelti. Nello specifico, per le filiere di Pitigliano sono stati selezionati: la chiesa di S. Francesco (fig. I), lontana dal centro storico, attualmente allo stato di rudere e non fruibile per qualsiasi tipo di attività; la chiesa di Santa Maria Maggiore (fig. 2) all'interno del borgo di Sovana, funzionante e pienamente accessibile, che secondo studi geofisici rivela al di sotto del livello pavimentale delle preesistenze; ed infine una tra le suppellettili sacre esposte attualmente nelle vetrine del museo, che su richiesta della committenza museale andava integrata da un nuovo sistema descrittivo dedicato alla descrizione dei dettagli compositivi. Per la filiera di Vetulonia sono stati selezionati reperti ritrovati durante le campagne di scavo del sito etrusco: un ciclo di bronzetti votivi, una stele di pietra con iscrizioni e vasellame dipinto. Contestualmente sono stati avviate ricerche sulla documentazione disponibile [Lecci, Pasqualotti 20 I9; Rivetti 20 I8] (figg. 3,4) e campagne di rilievo integrato (diretto e fotogrammetrico) per l'elaborazione e la definizione di elaborati 2D (piante, prospetti e sezioni) e 3D dello stato attuale consoni alla narrazione dei nuovi contenuti dei temi individuati e alla loro disposizione all'interno dei musei. Per il caso particolare della chiesa di S. Maria Maggiore l'approfondimento ha compreso anche delle indagini geofisiche effettuate dall'Istituto Nazionale di geofisica e Vulcanologia (INGV).

Terza fase. Sulla base dei dati rilevati e dei modelli realizzati sono stati affrontati studi sulle possibili soluzioni di valorizzazione e aumento della consapevolezza dei manufatti scelti, tramite la sperimentazione di nuove applicazioni tecnologiche. Qui l'attenzione si è focalizzata su uno degli obiettivi più innovativi della ricerca cioè quello dell'impiego del metodo della rappresentazione olografica all'interno del percorso museale, elaborando un progetto di allestimento. L'olografia viene trattata in questo contesto come un metodo di visualizzazione digitale che
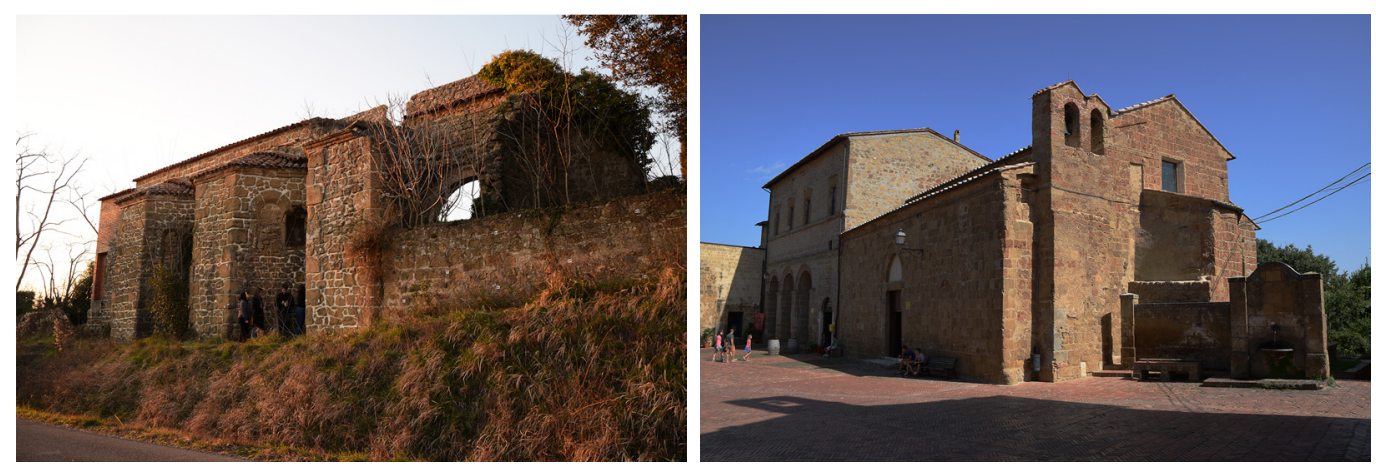

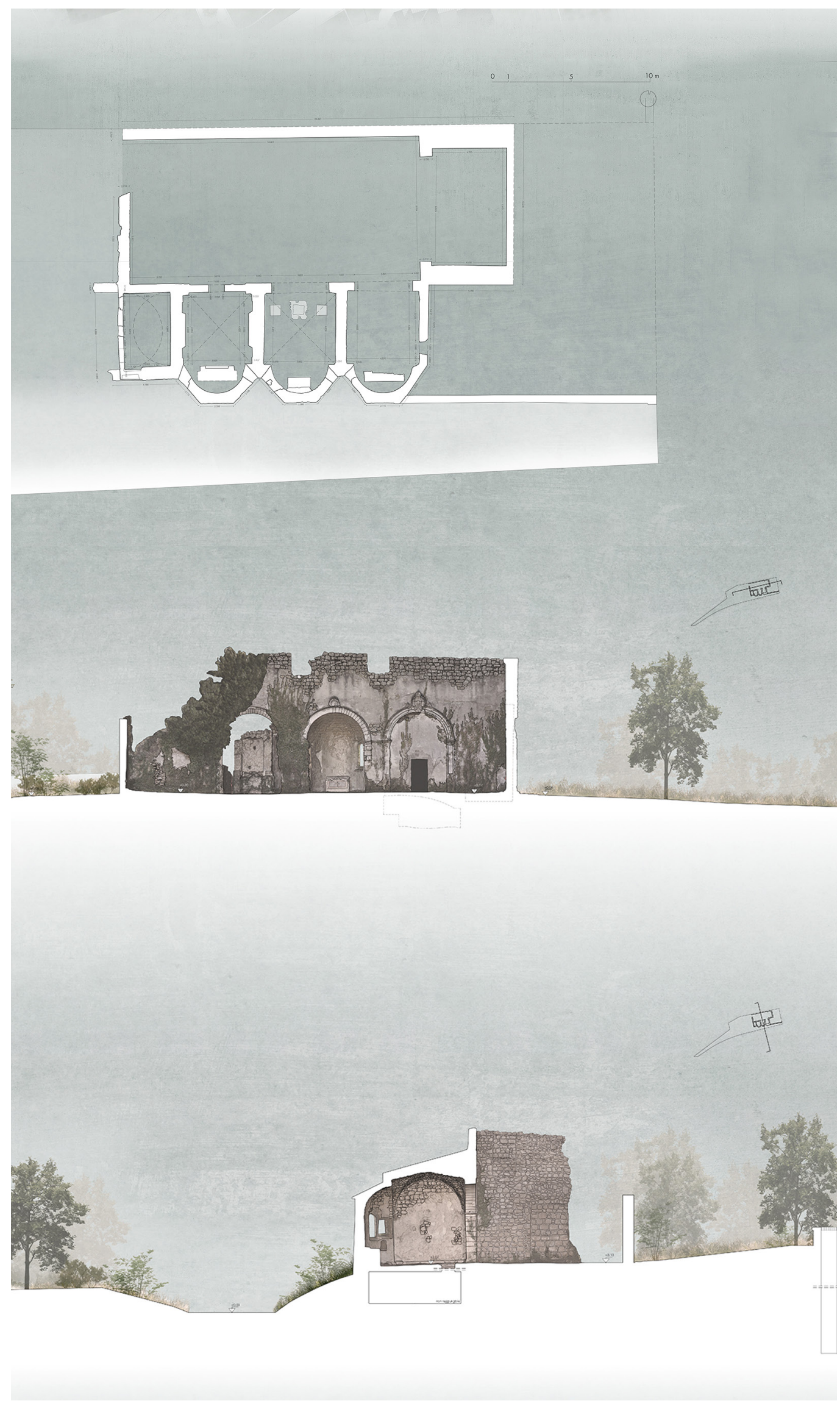

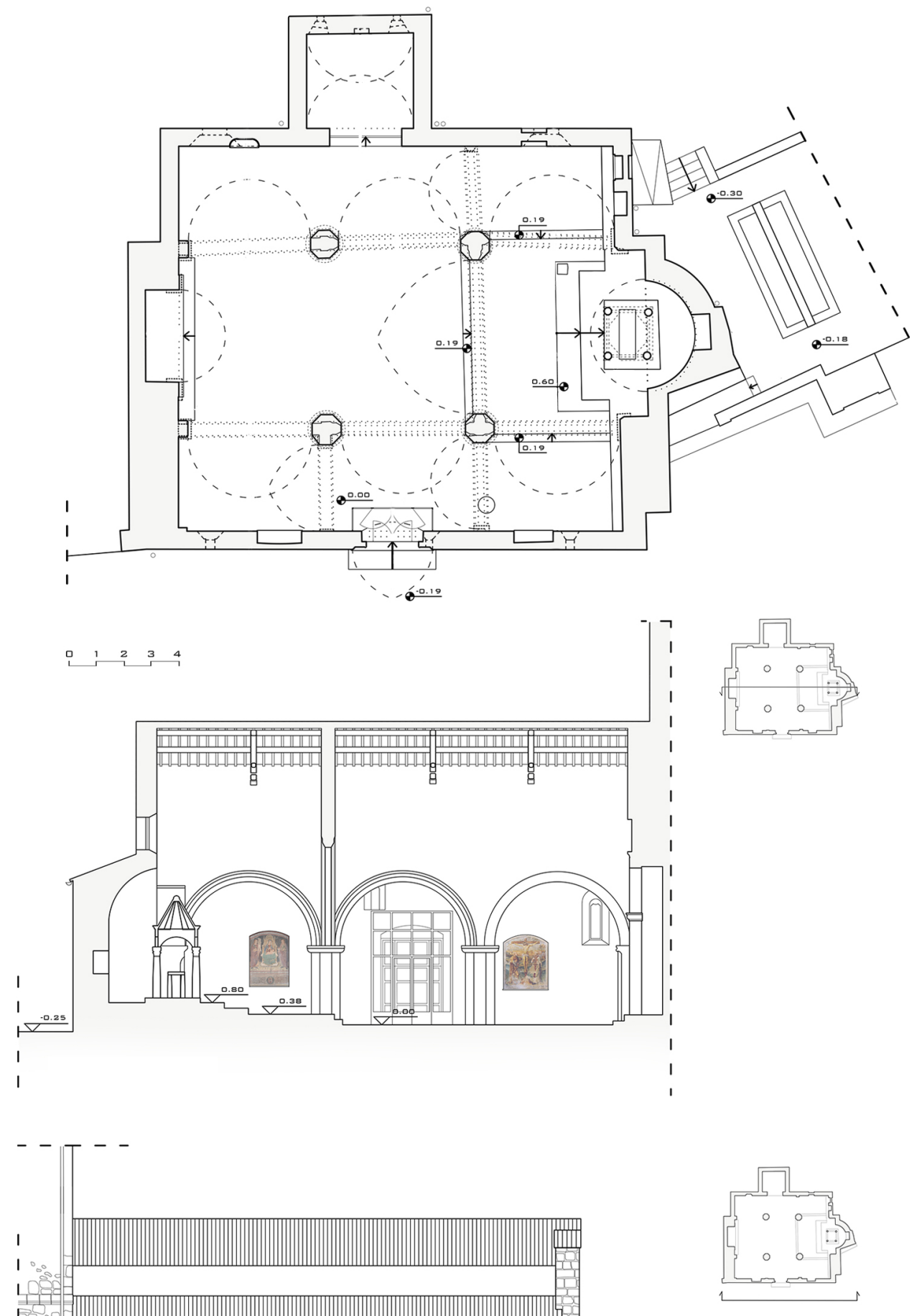


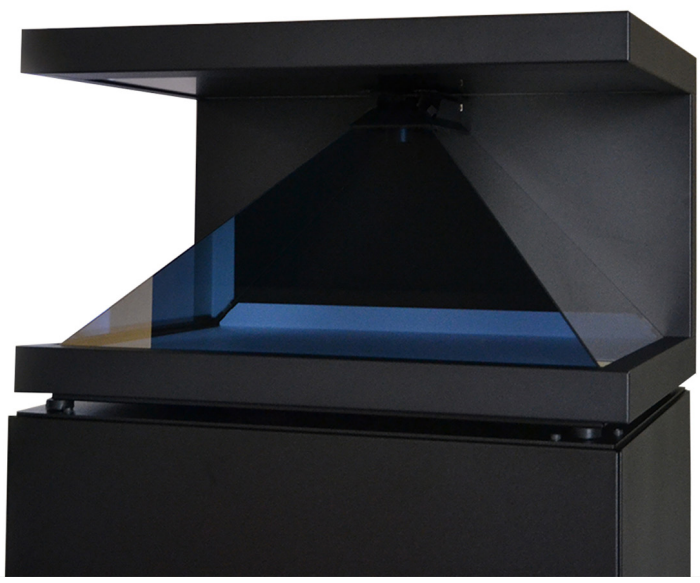

attraverso la proiezione di immagini/video dal display del dispositivo piramide, consente di ricreare fedelmente un'immagine 2D di oggetti esistenti o realizzati digitalmente, che appaiono in una visione tridimensionale. La rappresentazione virtuale realizzata con la tecnica olografica, l'ologramma, si rende visibile per mezzo della vetrina olografica (fig. 5) [Di Pietro 20 I7, pp. 4-I I]. In questo contesto viene utilizzato il digitale per la creazione di animazioni video che vengono poi proiettate sulle superfici trasparenti inclinate a $45^{\circ}$ di una piramide. Quello che si ottiene è la creazione di una scena in movimento riflessa all'interno del prisma che porta all'illusione di vederla fluttuare nell'aria quasi come si potesse toccare realmente.

II percorso museografico è stato ideato ripensando l'intero itinerario narrativo e le modalità di fruizione del museo da parte dell'utente, prevedendo la dislocazione di tre vetrine olografiche in differenti sale tematiche, dedicando ciascun espositore ad uno dei soggetti precedentemente scelti. Contemporaneamente il lavoro si è rivolto allo studio dei contenuti video da inserire nelle vetrine e al miglior modo in cui questi potessero essere articolati per una più efficace descrizione dei beni. Dunque, attraverso il materiale 2D e 3D ottenuto dal rilievo dei manufatti e degli oggetti, e studi interpretativi e di ricostruzione del passato applicati a questi, è stato possibile ideare una trama narrativa su cui basare dei contenuti video (figg. 6, 7) e strutturare degli storyboard (sequenza di immagini in ordine cronologico delle inquadrature che mostrano la sceneggiatura del video). Infine, si è proceduto alla ricerca e all'acquisto di tale strumentazione e all'installazione del primo espositore in una delle sale del museo pitiglianese. L'operazione attuativa del progetto è stata avviata con successo, procedendo con le prime prove per la messa a regime dei macchinari e la sperimentazione delle diverse potenzialità che essa mette a disposizione.

\section{Conclusioni}

L'immagine 3D e l'esposizione tridimensionali, concepite in questo progetto, lontano dall'essere solo estetiche rappresentazioni, si ripropongono di farsi strumento teso all'accordo tra saperi storico-umanistici e tecnologico-informatici, a vantaggio tanto della ricerca scientifica quanto del livello educativo della società, principale depositaria del patrimonio culturale. Pertanto, a livello operativo, le azioni attivate e le applicazioni proposte all'interno del piano di musealizzazione tecnologico del progetto DHoMus si indirizzano ad un potenziamento digitale della narrazione espositiva - nei contenuti e nelle modalità di accesso - tale che tra l'incontro tra la dimensione presente del visitatore e quella passata del bene musealizzato si instaura un dialogo cosciente e fruttuoso [Lecci, Prodi, Trovatelli, Vezzi 2019]. Per quanto riguardo lo sguardo al futuro, il progetto, oltre a prevedere come esito il compimento dei suoi obiettivi presso le filiere, si auspica che le esperienze maturate nel corso della sua attuazione forniscono un valido contributo ai fronti di ricerca che si muovono intorno alle materie museografiche e museologiche del cultural Heritage. 

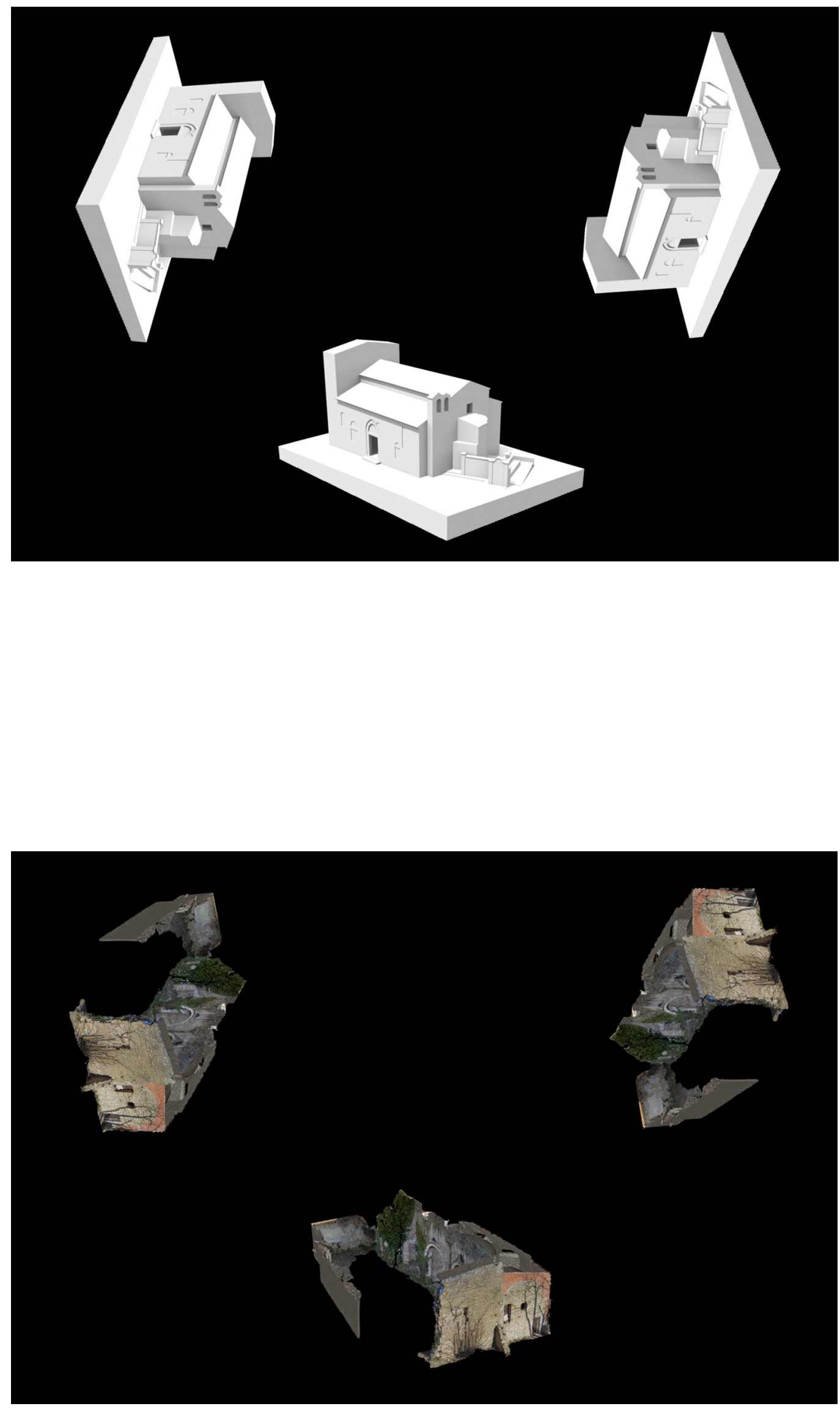


\section{Note}

[I] ICOM Statutes art. 3 para. I.

[2] POR FSE 2014, 2020.

\section{Riferimenti bibliografici}

Aiello L. (in corso di stampa). Le musée diffuse: stratégie pour valoriser les villages à risque d'abandon.L'étude de cas de Pitigliano entre patrimoine matériel et immatériel. In S. Mecca (a cura di). 8.5 Ripam, Vilages et quartiers à risque d'abandon. Strategies puor la connaissance, la valorisation et la restauration. Firenze, 25-26 novembre 2020. Firenze: Didapress.

De Benedictis C. (199I). Per una storia del collezionismo italiano. Fonti e documenti. Firenze: Ponte alle Grazie.

Di Pietro I. (2017). La nuova frontiera dei musei: digitalizzazione, comunicazione culturale e coinvolgimento. Dottorato di ricerca di Arti Visive, Performative e Mediali, ciclo XXIX, tutor prof.ssa M. Pigozzi. Alma Mater Studiorum, Università di Bologna.

Fiorio M.T. (20 I I). Il museo nella storia. Dallo "studiolo" alla raccolta pubblica. Milano: Mondadori.

Gabellone F. (2014a). Comunicazione dei Beni Culturali. In Gabellone F., Giannotta M.T., Dell'Aglio A. (a cura di). Fruizione di contesti inaccessibili. Il progetto "Marta Racconta", pp. 45-56. Lecce: Edizioni Grifo.

Gabellone F. (20 | 4b). Ambienti virtuali e fruizione arricchita. In Gabellone F., Giannotta M.T., Dell'Aglio A. (a cura di). Fruizione di contesti inaccessibili. Il progetto "Marta Racconta", pp. 31-43. Lecce: Edizioni Grifo.

Gabellone F. (20I4c). Approcci metodologici per una fruizione virtuale e arricchita dei Beni Culturali. In Arkos. Scienza, restauro, valorizzazione, $V$ serie, n. 5-6, pp. 7-18.

International Council Of Museums (ICOM) Statutes, 9th June 2017, Paris, France, art.3 para. I.

Lecci N., Pasqualotti L. (2019). Abitare il paesaggio storico. Progetto per Poggio Strozzoni a Pitigliano. Tesi di Laurea Magistrale in architettura (biennale), relatore F. Fabbrizzi, correlatore interno C.M.R. Luschi, correlatore esterno L. Aiello, M. Monari. Università degli Studi di Firenze.

Lecci N., Prodi F., Trovatelli F., Vezzi A. (2019). Experiencing Heritage Dynamic Through Visualization. Milano: GEORES.

Rafanelli S. (20 I8). II Museo Civico Archeologico "Isidoro Falchi" di Vetulonia. In Annali della fondazione per il museo "Claudio Faina", vol. XXV. Roma: Edizioni Quasara.

Rivetti D. (2018). La chiesa di Santa Maria nella profondità della sua storia. Tesi di Laurea in Scienze dell'Architettura, relatore prof. C.M.R.Luschi, correlatori proff. A. Ricci, L. Aiello, membro esterno M. Monari. Università degli Studi di Firenze.

Yamanouchi T., Maki N., Yanaka K. (2016). Holographic Pyramid Using Integral Photography. Kanagawa Institute of Technology. Proceedings of the 2nd World Congress on Electrical Engineering and Computer System and Science.

\section{Autori}

Alessandra Vezzi, Università degli Studi di Firenze, alessandra.vezzi@unifi.it Beatrice Stefanini, Università degli Studi di Firenze, beatrice.stefanini@unifi.it

Per citare questo capitolo: Alessandra Vezzi, Beatrice Stefanini (2021). Strategie di musealizzazione dinamica per nuovi ambiti di memoria: il progetto DHoMus/Dynamic Musealization Strategies for New Areas of Memory: the DHoMus Project. In Arena A. Arena M. Mediati D. Raffa P. (a cura di). Connettere Un disegno per annodare e tessere Linguggri Distanze Tecnologie. Atti del $42^{\circ}$ Convegno Internazionale dei. Docenti delle Discipline della Rapprestazione/Connecting. Drawing for weoving relationship. Langues Distances Technologies. Proceedings of the 42th International Conference of Representation Disciplines Teachers. Milano: FrancoAngeli, pp. 2722-2739. 


\title{
Dynamic Musealization Strategies for New Areas of Memory: the DHoMus Project
}

\author{
Alessandra Vezzi \\ Beatrice Stefanini
}

Abstract

The museum reality, a reflection of the cultural changes in the history of a society and its development, is structured today as an institution in constant evolution and in the constant reformulation of the boundaries of its identity. It sees itself as a 'place of memory' in which to collect and pass on the material and immaterial evidence of a more or less remote past that carries messages for one that is still near. This task finds its fulfilment in the research and construction of a living and active dialogue between what was, what is and what will be. The contemporary museum today is about to ask itself which technological answers correspond in the best way to the difficult task of combining the dimension of the exhibited good with that of its user.The present contribution illustrates a project of musealisation, in progress, which involves the University and the museums of small peripheral centres in Tuscany in a strategic collaboration. The project called DHoMus proposes, through applied research, to use the most advanced technologies for digital processing, in order to promote the valorisation of the museum structures and their use by a wider public.

\section{Parole chiave}

widespread museum, museum communication, 3D modelling, hologram, multimedia fruition.

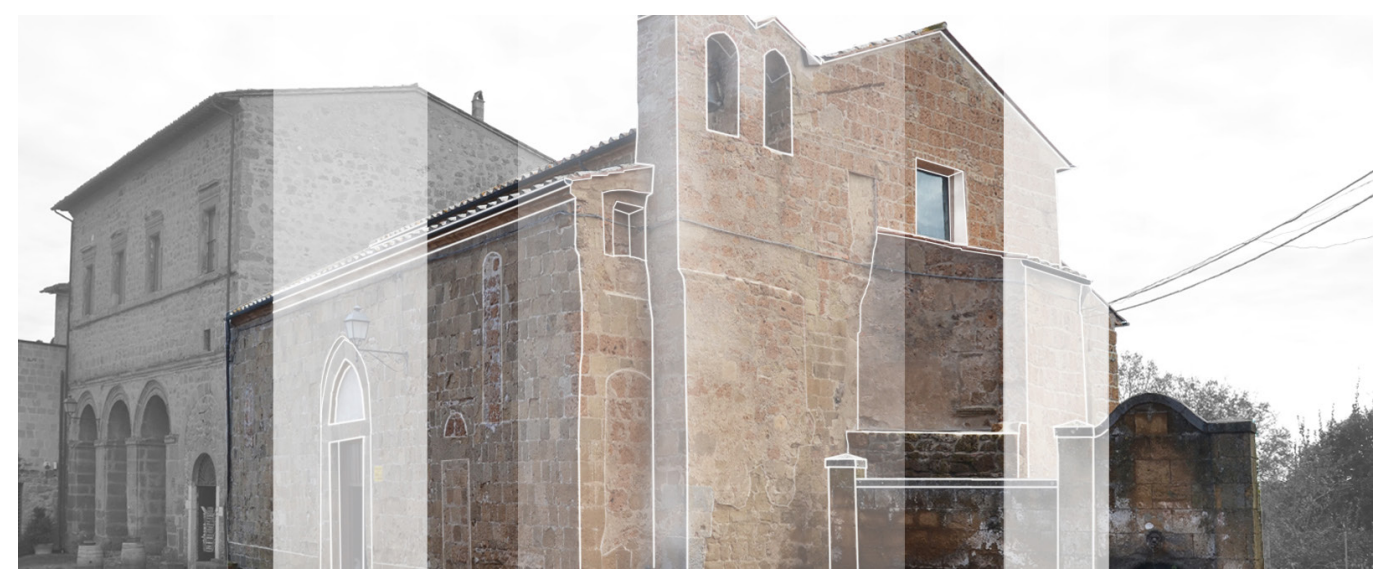




\section{Memory's position}

Historical memory, from the individual to the collective, in whatever cultural field one considers it, has always presented itself to man, who lives in his own present, as a separate reality with which comparison becomes inevitable. History tells us of a relationship that has taken on various inclinations according to the different contexts, both temporal and geographical, in which it has appeared. Even with all their differences, all these propensities with which man has dealt with memory have brought out and clarified its importance, its value as an essential part of the definition of an identity necessary for the maturation of a self-awareness capable of actively projecting itself into the future.

\section{Memory place: the museum}

One of the places where this dialogue has taken place is undoubtedly that of the museum: even before being set up in the institution we know today, it has brought together the past and the present and on this has laid the foundations of its own configuration. In the early days, between the 15th and 16 th centuries, this encounter was resolved in an action aimed at the private collection of works of art or rare and admirable objects; between the 18th and 19 th centuries there was a growing awareness of the cultural importance of contact with history for all men, regardless of their position in a constituted society: thus the modern museum began to appear. This is how the modern museum began to be imagined. From this point onwards, the perspective of the museum reality has been increasingly broadened on the basis of a reflection that has never ceased to question the terms of the role of this institution, which, in attempting to connect past and present, also discovers itself as a weaver of the future. As for today, regarding the most recent results of the scientific debate on this topic, the definition of 'museum' is eloquent, articulated in 2007 by the Statute of ICOM, (International Council of Museums): "A museum is a permanent, non-profit institution, at the service of society and its development, open to the public, which carries out research into the material and immaterial evidence of man and his environment, acquires, conserves, and communicates them, and specifically exhibits them for purposes of study, education and enjoyment" $[\mathrm{I}]$. Contemporary culture no longer sees the museum merely as a building for the collection and safekeeping of heritage, but rather as an institution engaged in the constant search for a dialectical, critical and creative exchange with it, through the never-abandoned path of conservation, enhancement and design. The great mission and challenge for museology from modern times to the present is to bring memory and its heritage up to date, so that it does not end up as a distant axiom to be assumed, but as a reality to be experienced as part of the present time. The latest frontier of museological studies, particularly in the Italian context, has led to the formulation and affirmation of the idea of the 'diffuse museum', as a model for the construction of a museum network that extends its action to the outside world, to the territory and to the population, as was illustrated at the Intermediate Conference, RIPAM 8.5 [Aiello 2020].

\section{Museum communication}

Considering today's social and cultural context, where continuous technological development has introduced new transmission mechanisms in different areas of human life, in the dimension of the contemporary museum, the communicative aspect has become a determining element within the strategy of fruition adopted [Gabellone 2014a, pp. 45-56]. Museum communication, far from the classical approach, turns to the experimentation and development of new systems which, based on visual, auditory and tactile languages, are able to bring a greater involvement of the public [Di Pietro 2017, pp. 4-II].The progressive interest of international museums in the use of new interactive technologies, in addition to the above-mentioned reasons, undoubtedly responds to other critical issues 
that this particular field of culture has identified and is facing. In fact, all the issues related to the decontextualisation of museum heritage, both movable and immovable, are well known; particularly significant issues when talking about archaeological heritage and monuments of historical and architectural importance. The reference is directed to those "sites that, in extreme conditions, are completely inaccessible"; to those monumental categories that "are poorly accessible because they are located in unfavourable positions or because their very conformation makes it difficult to use them", and for which "the need for conservation imposes drastic choices that limit or avert the dangers induced by a large number of visitors" [Gabellone 20I4a, pp. 45-56]. In addition to these cases, there are also the consequences of the now consolidated practice of 'stripping' archaeological sites of their most precious elements, cataloguing and displaying the finds in museum buildings, and narrating the site through forms of representation that are difficult for non-specialists to understand. Actions of this kind can only lead to a fragmentation of the contents of the object and thus to a partial and confused transmission of knowledge, thus impoverishing the effectiveness of museum communication. Faced with such situations, the technology coming from virtual space -such as 3D digital modelling, interactive and three-dimensional graphic animation- proves to be a valid tool for the formulation of methodological solutions, which by enhancing the communicative capacity of the representation, favour, and in some cases make possible, the fruition of the cultural heritage by a wide and diversified public.

\section{DHoMus project}

In the context of the themes described, the DHoMus project was launched in March 2020, conducted in collaboration between the Department of Architecture (scientific disciplinary sector ICAR/I7) of the University of Florence, and as Operators of the regional cultural and creative supply chain, the Diocesan Museum Palazzo Orsini of Pitigliano, and the Civic Archaeological Museum "Isidoro Falchi" of Vetulonia [2]. In view of the important role that museums play in the field of cultural heritage protection and in line with the emerging idea of the 'diffuse museum', the study proposes to design cognitive itineraries aimed at going beyond the mere aesthetic contemplation of cultural assets, but capable of bringing their intrinsic values to the fore.The project intends to make use of the most advanced technologies for the production of digital elaborations (video, holographic projections, animations) and tactile aids, from which intervention protocols of dynamic musealisation can be applied. The digital format is a medium that has always allowed the elaboration of contents able to involve the observer, allowing a knowledge of the subject with an informative didactic approach. The three-dimensional virtual representation of the hologram proposed here is an innovative approach to new forms of communication. The user, therefore, is led to be attracted by this type of visualisation, which allows him to move around the hologram having the illusion of being able to look at it from multiple sides. Currently, research is experimenting with the use of small-scale holograms to be inserted in holographic showcases already on the market, and is aiming in the future for their development on a larger scale and in more engaging forms. In the course of the project, various technologies will be tested in order to obtain different prototypes and usage models adapted to the different technological targets. Finally, pilot events will be organised in external museums and archaeological sites to test the functioning and the dissemination and enhancement potential.

The dynamism of such a system wants to operate on the relationship itself between visitor, museum and archaeological site or monument: with this it is fundamental the possibility to realise and make accessible through the direct sensorial experience, digital contents of some appropriately selected museum subjects. The objective pursued, therefore, looks both at the documentation and conservation of the museum heritage and at its valorisation, promoting communication and dissemination. The ultimate aim is also to develop methodologies that can make high-tech solutions available and sustainable also for peripheral museums. 


\section{In itinere}

The activities of the DHoMus project carried out its first year of work according to the following approach:

First phase. Through a series of preliminary surveys, the current state of the two museums and their related sites was ascertained. This phase initially included the historical study of the place, the museum complexes, the territorial context in which they are located, and the collection of material already present and available for future work. Then the sites were analysed in detail, with particular regard to their functions, routes and contents.

Second phase: This step consisted in the research of the subjects of particular relevance (from architecture to objects) that could be shown in digital format and become part of the story that is articulated in the museum route. At the same time, the most suitable technological supports for a better representation of the different themes were evaluated. Specifically, the following were selected for the Pitigliano sectors: the church of S. Francesco (fig. I), far from the historical centre, currently in a state of ruin and not usable for any type of activity; the church of Santa Maria Maggiore (fig. 2) in the village of Sovana, in working order and fully accessible, which, according to geophysical studies, reveals pre-existing structures below the floor level; and finally, one of the sacred furnishings currently displayed in the museum showcases, which at the request of the museum patrons needed to be integrated with a new descriptive system dedicated to the description of compositional details. For the Vetulonia branch, finds discovered during excavation campaigns at the Etruscan site were selected: a cycle of votive bronzes, a stone stele with inscriptions and painted pottery. At the same time, research was carried out on the available documentation [Lecci, Pasqualotti 20 19; Rivetti 20 I8] (figs. 3,4 ) and integrated survey campaigns (direct and photogrammetric) were undertaken for the elaboration and definition of 2D (plans, elevations and sections) and 3D drawings of the current state in order to narrate the new contents of the identified themes and their arrangement in the museums. For the particular case of the church of S. Maria Maggiore, the in-depth study also included geophysical surveys carried out by the National Institute of Geophysics and Volcanology (INGV).

Third phase. On the basis of the data collected and the models created, studies were carried out on possible solutions for enhancing the value and increasing the awareness of the selected artefacts, through the experimentation of new technological applications. Here the focus was on one of the most innovative objectives of the research, namely the use of the method of holographic representation within the museum itinerary, by developing an exhibition design. Holography is treated in this context as a method of digital visualisation which, through the projection of images/videos from the display of the pyramid device, makes it possible to faithfully recreate a 2D image of existing or digitally realised objects, which appear in a three-dimensional. The virtual representation realised with the holographic technique, the hologram, is made visible through the holographic showcase (fig. 5) [Di Pietro 20 I7, pp. 4-I I]. In this context, digital technology
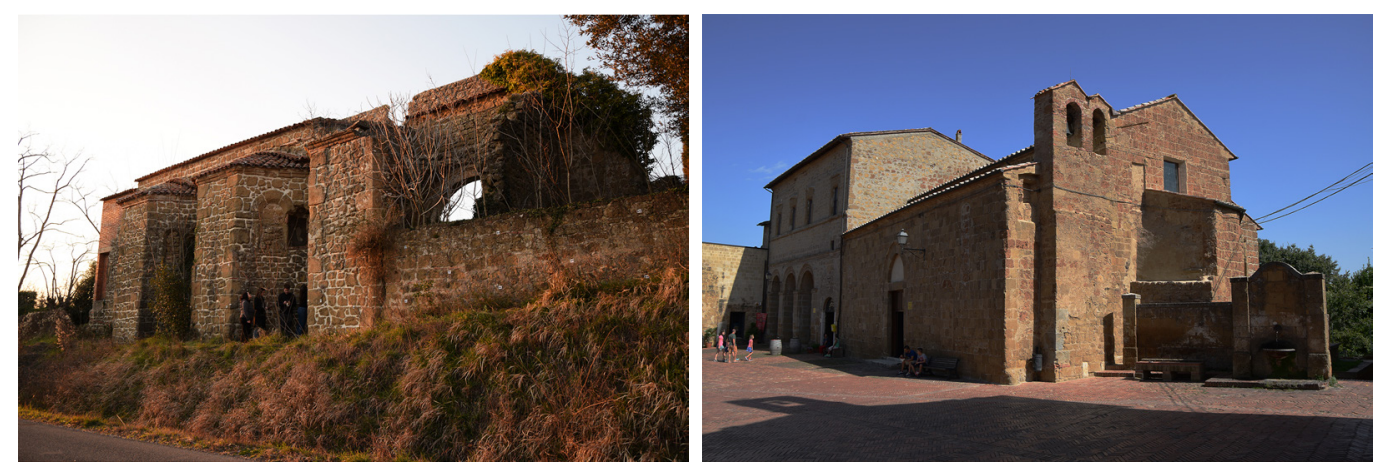

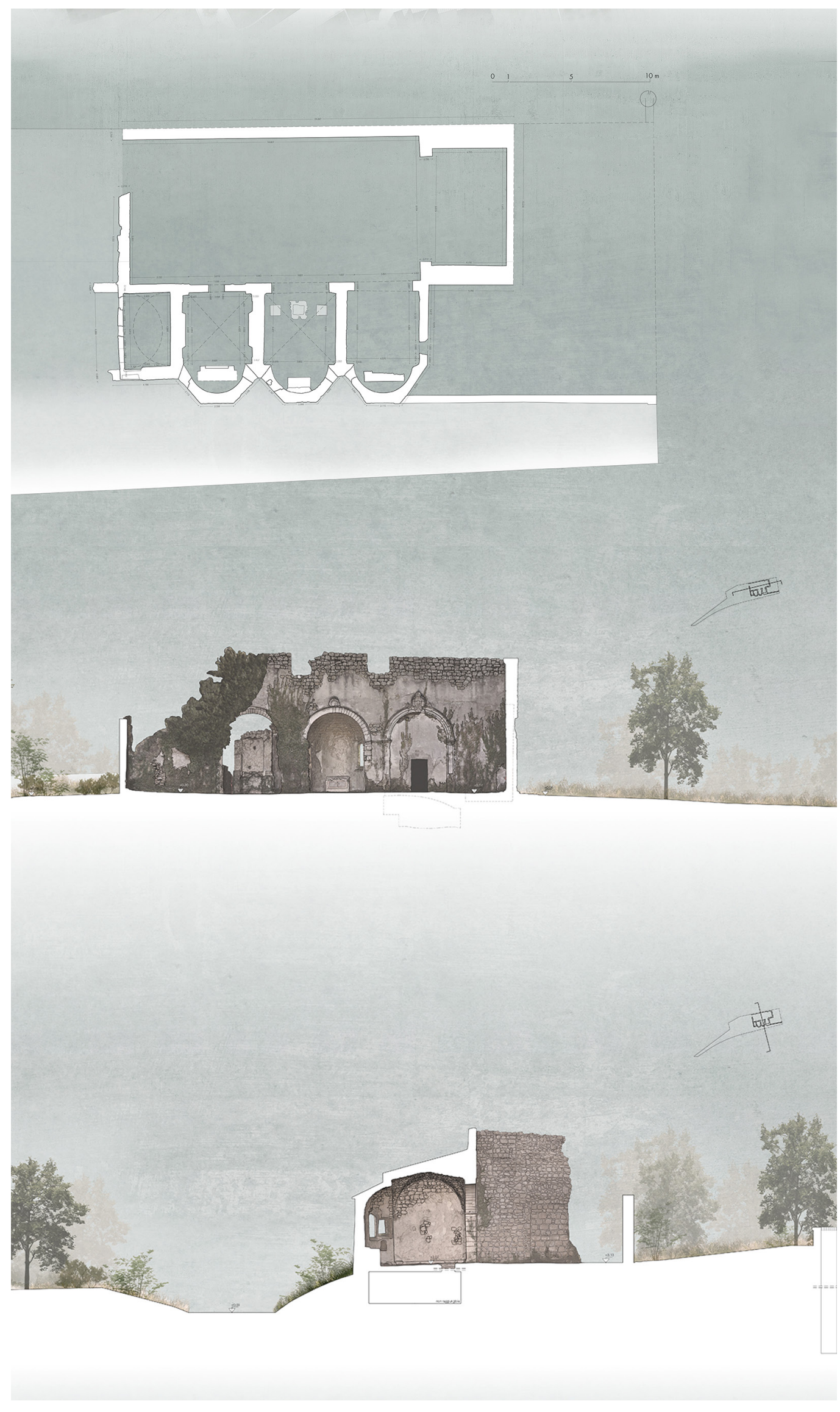

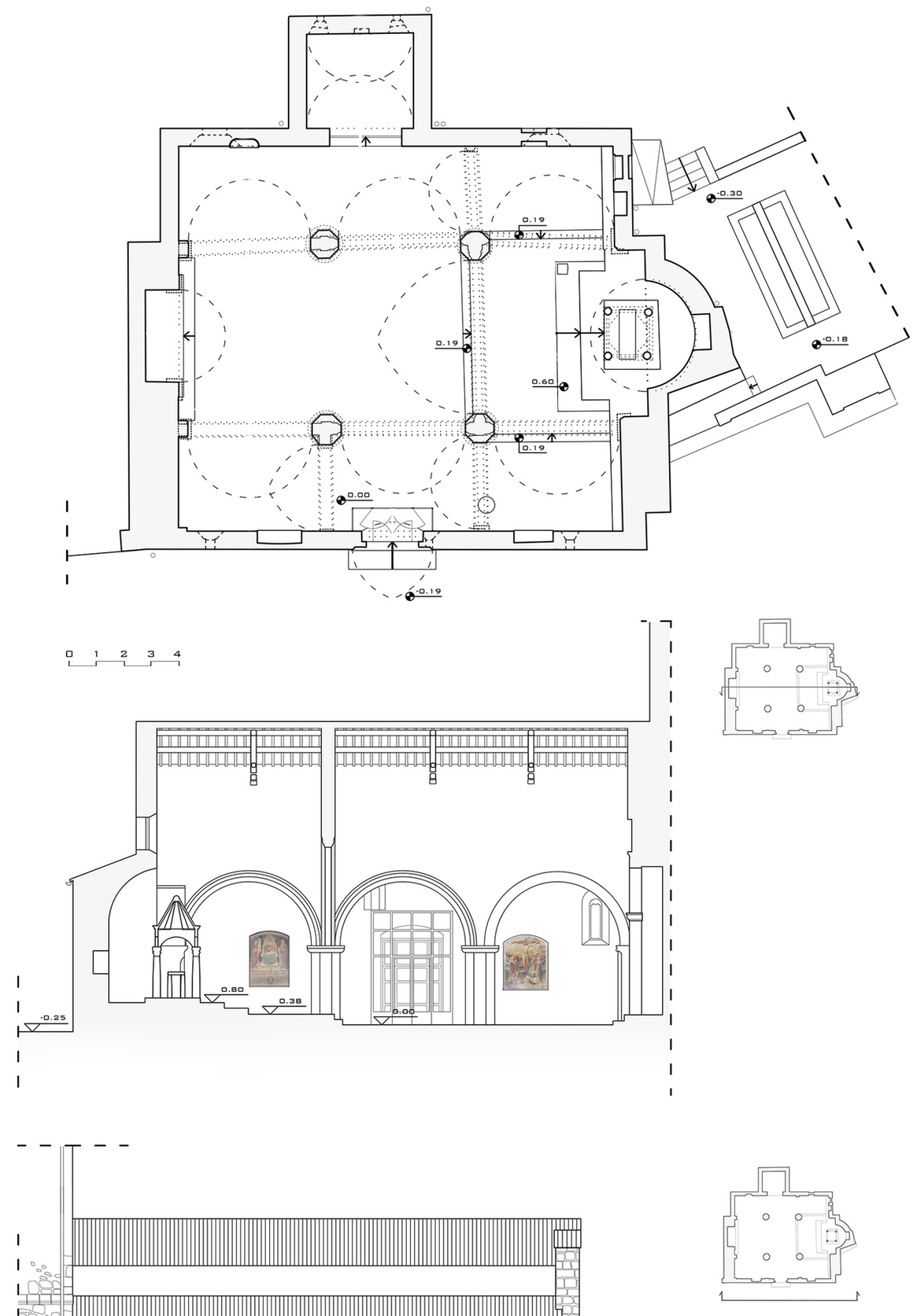


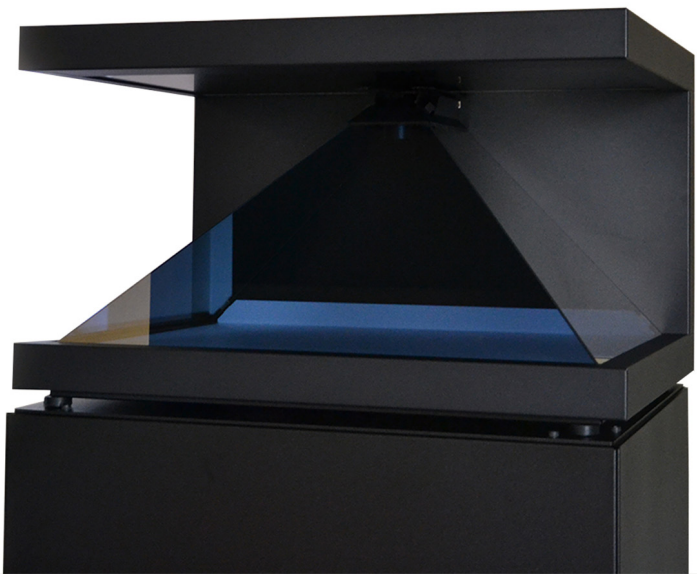

is used to create the video animation which is then projected onto the transparent surfaces of a pyramid, inclined at $45^{\circ}$. What we get is the creation of a moving scene reflected inside the prism that leads to the illusion of seeing it floating in the air almost as if you could touch it.

The museographic route has been designed by rethinking the whole narrative itinerary and the way the user can use the museum, by placing three holographic showcases in different thematic rooms, dedicating each display to one of the previously chosen subjects. At the same time, the work turned to the study of the video contents to be inserted in the showcases and the best way in which they could be articulated for a more effective description of the goods. Therefore, using the 2D and 3D material obtained from the survey of the artefacts and objects, and interpretative studies and reconstructions of the past applied to them, it was possible to devise a narrative plot on which to base the video contents (figs. 6, 7) and structure the storyboards (sequence of images in chronological order of the shots showing the video script). Finally, this equipment was researched and purchased, and the first display was installed in one of the rooms of the museum in Pitigliano. The implementation of the project was successfully started, proceeding with the first tests to set up the equipment and experiment with the different potentialities it offers.

\section{Conclusions}

The 3D image and the three-dimensional exposition, thought in this project, far from being only aesthetic representations, propose to become an instrument aimed at the agreement between historical-humanistic and technological-computer knowledge, to the advantage of the scientific research as well as of the educational level of the society, main custodian of the cultural heritage. Therefore, at an operational level, the actions activated and the applications proposed within the technological musealisation plan of the DHoMus project are directed towards a digital enhancement of the exhibition narration - in its contents and access modes - so that a conscious and fruitful dialogue is established between the encounter between the visitor's present dimension and the past dimension of the musealised heritage [Lecci, Prodi, Trovatelli, Vezzi 2019]. As far as the future is concerned, the project, besides foreseeing as an outcome the fulfilment of its objectives at the supply chains, hopes that the experiences gained during its implementation will provide a valuable contribution to the research fronts moving around the museographic and museological subjects of cultural heritage. 

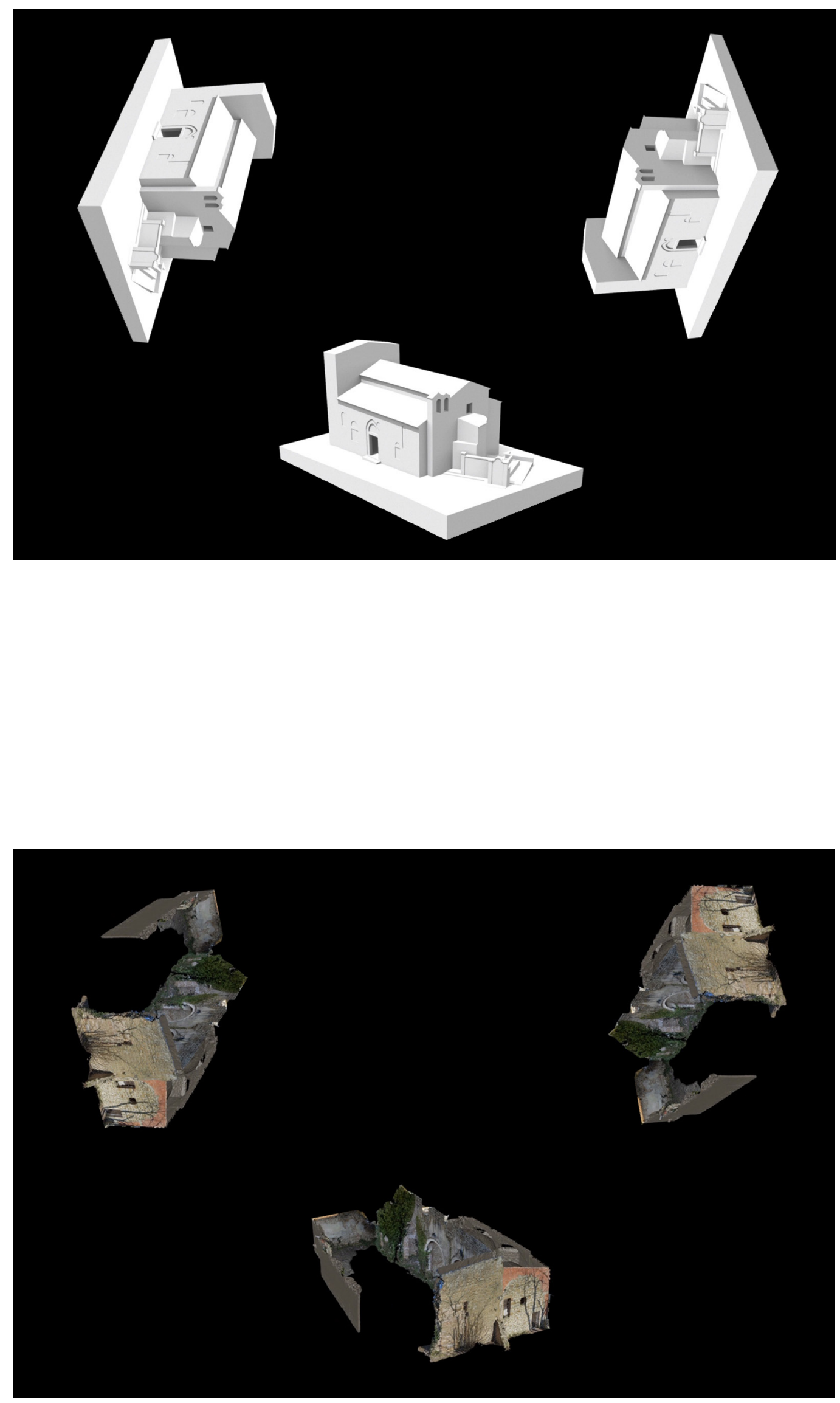


\section{Notes}

[I] ICOM Statutes art. 3 para. I.

[2] POR FSE 2014, 2020.

\section{References}

Aiello L. (in corso di stampa). Le musée diffuse: stratégie pour valoriser les villages à risque d'abandon.L'étude de cas de Pitigliano entre patrimoine matériel et immatériel. In S. Mecca (a cura di). 8.5 Ripam, Vilages et quartiers à risque d'abandon. Strategies puor la connaissance, la valorisation et la restauration. Firenze, 25-26 novembre 2020. Firenze: Didapress.

De Benedictis C. (1991). Per una storia del collezionismo italiano. Fonti e documenti. Firenze: Ponte alle Grazie.

Di Pietro I. (2017). La nuova frontiera dei musei: digitalizzazione, comunicazione culturale e coinvolgimento. PhD thesis in Arti Visive, Performative e Mediali, ciclo XXIX, tutor prof. M. Pigozzi. Alma Mater Studiorum, Università di Bologna.

Fiorio M.T. (20 I I). Il museo nella storia. Dallo "studiolo" alla raccolta pubblica. Milano: Mondadori.

Gabellone F. (20|4a). Comunicazione dei Beni Culturali. In Gabellone F., Giannotta M.T., Dell'Aglio A. (a cura di). Fruizione di contesti inaccessibili. Il progetto "Marta Racconta", pp. 45-56. Lecce: Edizioni Grifo.

Gabellone F. (20 | 4b). Ambienti virtuali e fruizione arricchita. In Gabellone F., Giannotta M.T., Dell'Aglio A. (a cura di). Fruizione di contesti inaccessibili. II progetto "Marta Racconta", pp. 31-43. Lecce: Edizioni Grifo.

Gabellone F. (20I4c). Approcci metodologici per una fruizione virtuale e arricchita dei Beni Culturali. In Arkos. Scienza, restauro, valorizzazione, $V$ serie, n. 5-6, pp. 7- I8.

International Council Of Museums (ICOM) Statutes, 9th June 2017, Paris, France, art.3 para. I.

Lecci N., Pasqualotti L. (2019). Abitare il paesaggio storico. Progetto per Poggio Strozzoni a Pitigliano. Bachelor's thesis in Architettura, supervisor F. Fabbrizzi, internal co-supervisor prof. C.M.R. Luschi, external co-supervisor prof. L. Aiello, M. Monari. Università degli Studi di Firenze.

Lecci N., Prodi F., Trovatelli F., Vezzi A. (2019). Experiencing Heritage Dynamic Through Visualization. Milano: GEORES.

Rafanelli S. (20 I8). II Museo Civico Archeologico "Isidoro Falchi" di Vetulonia. In Annali della fondazione per il museo "Claudio Faina", vol. XXV. Roma: Edizioni Quasara.

Rivetti D. (20 I 8). La chiesa di Santa Maria nella profondità della sua storia. Bachelor's thesis in Scienze dell'Architettura, supervisor prof. C.M.R.Luschi, co-supervisors proff. A. Ricci, L. Aiello, external co-supervisor M. Monari. Università degli Studi di Firenze.

Yamanouchi T., Maki N., Yanaka K. (2016). Holographic Pyramid Using Integral Photography. Kanagawa Institute of Technology Proceedings of the 2nd World Congress on Electrical Engineering and Computer System and Science.

\section{Authors}

Alessandra Vezzi, Università degli Studi di Firenze, alessandra.vezzi@unifi.it Beatrice Stefanini, Università degli Studi di Firenze, beatrice.stefanini@unifi.it

To cite this chapter. Alessandra Vezzi, Beatrice Stefanini (202I). Strategie di musealizzazione dinamica per nuovi ambiti di memoria: il progetto DHoMus/Dynamic Musealization Strategies for New Areas of Memory: the DHoMus Project. In Arena A., Arena M., Mediati D., Raffa P. (a cura di). Connettere. Un disegno per annodare e tessere. Linguaggi Distanze Tecnologie. Atti del $42^{\circ}$ Convegno Internazionale dei Docenti delle Discipline della Rappresentazione/Connecting. Drawing for weaving relationship. Languages Distances Technologies. Proceedings of the 42th International Conference of Representation Disciplines Teachers. Milano: FrancoAngeli, pp. 2722-2739. 